\title{
29. PALYNOLOGICAL INVESTIGATION OF THE TRIASSIC-MIDDLE JURASSIC SEQUENCES AT DEEP SEA DRILLING PROJECT LEG 79, SITES 545, 546, AND HOLE 547B, OFF CENTRAL MOROCCO'
}

\author{
J. P. G. Fenton, Robertson Research Petroleum Services Limited ${ }^{2}$
}

\begin{abstract}
Twenty-five samples from selected cored intervals of problematic Triassic-Jurassic age from Sites 545, 546, and Hole 547B have been analyzed palynologically to aid age determination. Section 545-73-1 yielded a marine palynoflora of Sinemurian-Bajocian age. A palynoflora of nonmarine origin and assigned a Rhaetian-Hettangian age was recovered from halite in Section 546-18-2. Marine palynofloras of Hettangian-early Pliensbachian age were recovered from Sample 547B-24,CC to Section 547B-14-2. Sections 547B-28-1 to 547B-25-3 yielded impoverished nonmarine palynofloras to which only a general Rhaetian-Hettangian age could be given.
\end{abstract}

\section{INTRODUCTION}

The object of Leg 79 of the Deep Sea Drilling Project was to drill a series of holes west of the Mazagan Plateau, part of the Moroccan Continental Shelf, in order to document the Jurassic environment of rifting and early subsidence history of a segment of passive margin bordering the proto-Atlantic. Sites 545, 546, and Hole 547B were drilled seaward of the Mazagan Escarpment, which flanks the western edge of the Mazagan Plateau, within a 50-km-wide zone where halite diapirs and gneissic basement highs penetrate a 4-km-thick sedimentary pile.

It was believed that these structures had uplifted Upper Triassic-Lower Jurassic sediments close to the seafloor and would allow dating of the earliest stage of Atlantic evolution (Hinz et al., 1982). Samples were selected to determine the age and stratigraphic relationship of the lower cored intervals at Sites 545, 546, and Hole 547B.

\section{BIOSTRATIGRAPHIC RESULTS}

The appendix alphabetically lists all palynomorph species recorded. Palynological assemblages were recovered using standard preparation techniques.

\section{Site 545}

This site is located near the foot of the steep part of the Mazagan Escarpment, latitude $33^{\circ} 39.9^{\prime} \mathrm{N}$, longitude $9^{\circ} 21.9^{\prime} \mathrm{W}$, in a water depth of $3150 \mathrm{~m}$ with a sub-bottom depth of $701 \mathrm{~m}$. A $354 \mathrm{~m}$ section was recovered from Cores 1 to 75 (Hinz et al., 1982).

A single sample (545-73-1, 11-13 cm) of calcareous mudstone, which occurs within an overall sandy limestone and calcareous siltstone sequence, was analyzed from this site. The marine palynoflora recovered is dominated by terrestrially derived miospores, represented by undifferentiated bisaccate pollen, Cerebropollenites me-

\footnotetext{
${ }^{1}$ Hinz, K., Winterer, E. L., et al., Init. Repts. DSDP, 79: Washington (U.S. Govt. Printing Office).

2 Address: Robertson Research Petroleum Services Limited, Llanrhos, Llandudno, Gwy. nedd, North Wales, U.K.
}

sozoicus, Deltoidospora spp., Classopollis spp., Leptolepidites sp., Kraeuselisporites reissingeri, and Duplexisporites problematicus. Microfossils and algae are represented by foraminiferal test linings, large leiospheres, and Botryococcus sp.

While the presence of Cerebropollenites mesozoicus indicates an age no older than Sinemurian (Morbey, 1978; Boutet, 1981), the simultaneous occurrence of Kraeuselisporites reissingeri suggests an age no younger than Bajocian. The latter species is considered in northwest Europe to possess a stratigraphic range of Rhaetian-Bajocian (Morbey, 1978; Boutet, 1981).

Foraminiferal test linings are relatively numerous, while the freshwater/brackish alga Botryococcus sp. is a common component. The colonies of Botryococcus sp. are often large and well preserved, implying limited transportation prior to incorporation within the sediment.

Structured humic laths are numerous and are associated with common fragments of well-preserved plant cuticle and a high proportion of amorphous humic kerogen. The overall kerogen recovered from Sample 545-73-1, $11-13 \mathrm{~cm}$ is considered to reflect deposition within a proximal marine location, characterized by the input of components (e.g., Botryococcus sp.) from nearby freshwater/brackish environments.

\section{Site 546}

This site is located at latitude $33^{\circ} 46.7^{\prime} \mathrm{N}$, longitude $9^{\circ} 33.9^{\prime} \mathrm{W}$ in a water depth of $3992 \mathrm{~m}$ with a sub-bottom depth of $192 \mathrm{~m}$. Cores 1-21 resulted in the recovery of $118.5 \mathrm{~m}$ of section. Site 546 , about $25 \mathrm{~km}$ northwest of Site 545 , was drilled to determine the nature of a pronounced structural high, capped by a thin mantle of hemipelagic Miocene-Pleistocene sediments. The Cenozoic sediments rest unconformably upon halite banded with thin claystones within which the hole terminated (Hinz et al., 1982).

A single sample $(546-18-2,116 \mathrm{~cm})$ from the halite was analyzed and yielded an assemblage composed of carbonized palynomorphs exhibiting a Staplin Thermal Alteration Index (TAI) of 3. A palynoflora composed entirely of nonmarine, terrestrially derived components 
was recovered. Miospores present include Araucariacites australis, Corollina meyeriana, Perinopollenites elatoides, Deltoidospora sp., Cycadopites sp., and undifferentiated bisaccate pollen. The assemblage is overwhelmingly dominated (over $80 \%$ ) by pollen grains assignable to Corollina meyeriana. In northwest Europe large numbers of this taxon occur in the Norian-Rhaetian (Morbey, 1978; Visscher and Brugman, 1981; Boutet, 1981), while large numbers in the Scotian Shelf and Grand Banks regions of offshore southeastern Canada have been recovered from sediments attributable to the Corollina meyeriana Peak Zone of Rhaetian-Hettangian age (Bujak and Williams, 1977). Microfloras dominated by Corollina meyeriana also have been recorded by Cornet and Traverse (1975) from the Shuttle Meadow Formation, that is earliest Jurassic in age, from the Hartford Basin in Connecticut and Massachusetts, northeastern United States.

Age-diagnostic taxa are sparse in the assemblage recovered from Sample 546-18-2, $116 \mathrm{~cm}$. The occurrence of Perinopollenites elatoides, however, indicates an age no older than Rhaetian, while no specific taxa were recorded to accurately establish the youngest age limit. The overall composition, however, suggests an age no younger than Hettangian.

Large quantities of small, abraded, humic laths of vitrinite and inertinite dominate the kerogen. Fragments of plant cuticle are rare.

\section{Hole 547B}

This hole is located structurally downflank from the gneissic basement high penetrated at Site 544, lying approximately $5 \mathrm{~km}$ west of Hole 547B. The reentry Hole 547B was drilled in a water depth of $3940.5 \mathrm{~m}$ at latitude $33^{\circ} 46.8^{\prime} \mathrm{N}$, longitude $9^{\circ} 21.0^{\prime} \mathrm{W}$ with a sub-bottom depth of $1030 \mathrm{~m}$. Cores 1-36 were taken between 724.5 and $1030 \mathrm{~m}$ (Hinz et al., 1982). Twenty-three samples have been analyzed palynologically from two lithological units, Unit VII and Subunit VIB, the latter being overlain by limestone-rich facies of Early to Late Jurassic age. The stratigraphic distribution of taxa recorded is shown in Figure 1.

\section{Unit VII}

The lithology of this unit, in which the hole terminated, principally comprises grayish red sandy mudstone, although interbeds of dark gray sandy mudstone occur in the upper part.

Three samples from Sections 547B-36-1 to 547B-28-3 proved to be barren of palynomorphs, the only kerogen recovered being small abraded laths of oxidized (inertinitic) humic plant debris. The absence of palynomorphs and unoxidized humic plant debris is probably a result of syndepositional, subaerial oxidation.

The recovery of five impoverished, nonmarine palynofloras from Sections 547B-28-1 to 547B-25-3 indicates the periodic establishment of reducing conditions suitable for the preservation of unoxidized kerogen in the younger part of this unit. Although no age determination can be made on the palynofloras recovered from Section 547B-28-1 to 547B-26-1, the occurrence of a spe-

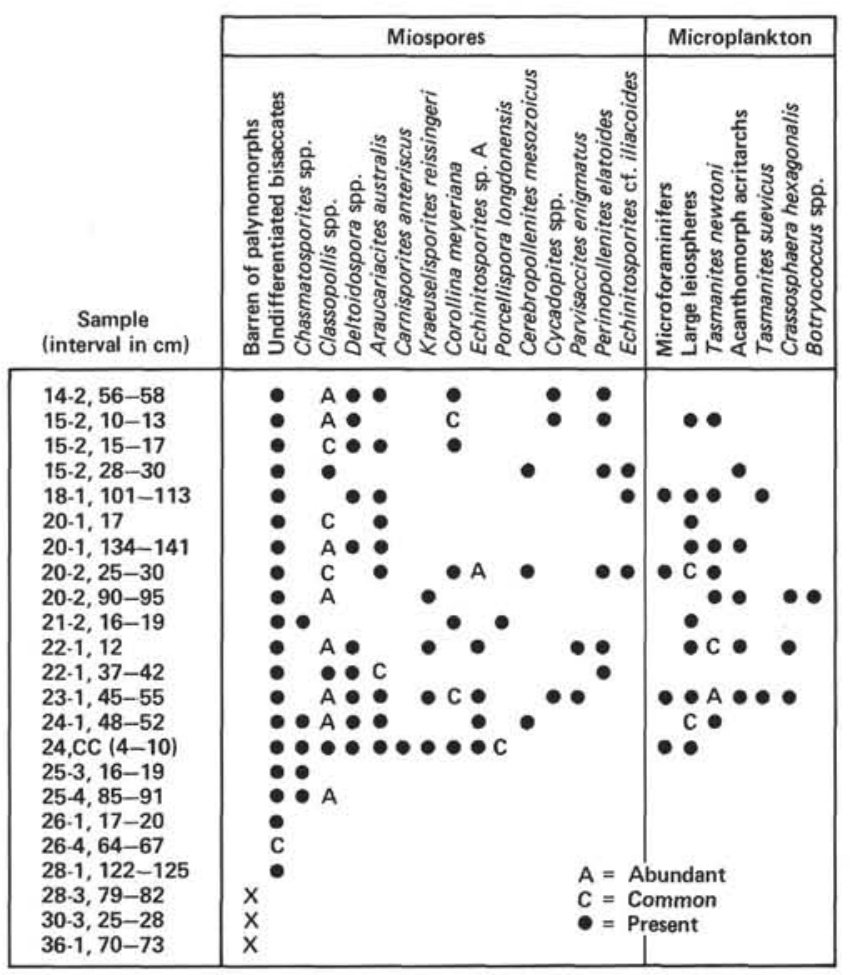

Figure 1. Stratigraphic distribution of taxa recorded from Hole 547B.

cies of Chasmatosporites indicates an age no older than Rhaetian for Section 547B-25-4. Within the same sample abundant specimens of Classopollis are present. This morphotype is considered to make its stratigraphic appearance in the Rhaetian of northwest Europe (Morbey, 1978; Visscher and Brugman, 1981). Large numbers of Classopollis are first encountered within the Hettangian of the Aquitaine Basin (Boutet, 1981); while in offshore southeastern Canada, high numbers have been sporadically recorded within the Corollina meyeriana Peak Zone of Rhaetian-Hettangian age or more consistently in the Cycadopites subgranulosus Assemblage Zone of Hettangian-Sinemurian age (Bujak and Williams, 1977). In the absence of positive age-diagnostic criteria and the age assigned to the overlying Subunit VIB, only a general Rhaetian-Hettangian age can be assigned.

\section{Subunit VIB}

Organic-rich olive black and olive gray mudstones, dolomitic limestone-mudstone breccias, and calcareous wackestone breccias are the dominant lithologies in this subunit. Fifteen relatively homogeneous palynofloras were recovered from Sample 547B-24,CC to Section 547B14-2, dominated by gymnosperm pollen and of low taxonomic diversity. Persistent components include undifferentiated bisaccates, Deltoidospora spp., Araucariacites australis, and Corollina meyeriana, while the dominant miospore component is pollen grains attributable to Classopollis, which often occur in tetrads or clusters of up to 15 individuals.

Palynofloras recovered are closely comparable to those described from the Lower Jurassic sediments of the Sco- 
tian Shelf and Grand Banks region of offshore southeastern Canada by Bujak and Williams (1977) and the Hartford Basin in Massachusetts and Connecticut, northeastern United States (Cornet and Traverse, 1975).

Dinoflagellate cysts are absent, marine microfossils being represented throughout Subunit VIB by low numbers of acanthomorph acritarchs, foraminiferal test linings, and the prasinophycean algae assignable to large leiospheres, Crassosphaera hexagonalis, Tasmanites newtoni, and T. suevicus. Although not of age-diagnostic value, the absence of dinoflagellate cysts, such as species of Nannoceratopsis, tentatively indicates a pre-late Pliensbachian-Toarcian age for Subunit VIB (i.e., preNannoceratopsis gracilis Assemblage Zone of Bujak and Williams, 1977).

Specimens of Classopollis are common to abundant throughout the subunit, a feature tentatively suggesting affinities with the Cycadopites subgranulosus Assemblage Zone and Echinitosporites cf. iliacoides Assemblage Zone of Hettangian-Sinemurian and Sinemurianearly Pliensbachian ages, respectively (Bujak and Williams, 1977).

An age no older than Hettangian, by comparison with Bujak and Williams (1977), is indicated in Sample 547B24,CC by the presence of Echinitosporites sp. A. Bujak and Williams. Common specimens of Porcellispora longdonensis are present in the same assemblage. This feature is considered to support a Hettangian age, as this species, which is considered by Bujak and Williams (1977) to possess a range of Rhaetian-Sinemurian in offshore Canada, is most numerous within strata of RhaetianHettangian age (Boutet, 1981). Specimens of Carnisporites anteriscus, which have only been recorded by Morbey (1975) from the Rhaetian, are also present in Sample 547B-24,CC. Due to the lack of published records, however, an extension of its stratigraphic range into the Hettangian cannot be excluded. Specimens of Kraeuselisporites reissingeri (many in tetrads) also occur in Sample 547B-24,CC suggesting, by analogy with Bujak and Williams (1977), an age no older than Hettangian. However, in northwest Europe this taxon occurs in sediments as old as Rhaetian (Morbey, 1978). Tetrads of K. reissingeri occur up to Sample 547B-22-1, $12 \mathrm{~cm}$, while only individual specimens occur above this, up to Sample 547B-20-2, 90-95 cm. Cerebropollenites mesozoicus appears in Sample 547B-24-1, 48-52 cm, indicating an age no older than Sinemurian (Morbey, 1978; Boutet, 1981).

Abundant specimens of Echinitosporites sp. A Bujak and Williams are present in Sample 547B-20-2, 25-30 cm and are associated with Echinitosporites cf. iliacoides. Bujak and Williams (1977) record the latter taxon as having a total stratigraphic range of Hettangian-early Pliensbachian. Specimens of Porcellispora longdonensis are encountered in Sample 547B-21-2, 16-19 cm, indicating by comparison with the Aquitaine Basin (Boutet, 1981 ) an age no younger than Hettangian, although $\mathrm{Bu}-$ jak and Williams (1977) record it up to the Sinemurian, and Van Erve (1977) records specimens from northeastern Italy in strata dated as late Pliensbachian-early Toarcian. Echinitosporites cf. iliacoides occurs in low numbers up to Sample 547B-15-2, 28-30 cm, suggesting an age no younger than early Pliensbachian for this horizon (Bujak and Williams, 1977).

Kerogen is abundant throughout most of Subunit VIB. The organic-rich mudstones are, in general, dominated by amorphous matter of sapropelic origin, while kerogen from breccias contains high proportions of terrestrially derived humic components in addition to amorphous material.

The palynofloras recovered suggest deposition within a marine environment, characterized by abnormal (possibly weak or fluctuating) surface salinities indicated by the dominance of prasinophycean algae in the microplankton assemblages. The predominance of amorphous matter, derived from degraded sapropelic (?algal) material, suggests the prevalence of oxygen-deficient conditions at or near the sediment/water interface. The increased humic kerogen content observed in the samples from breccia horizons is considered to reflect the introduction of components from terrestrial environments, via debris flows, into an essentially anoxic basin. Miospore assemblages suggest a low diversity macroflora developed upon the fringing hinterland, dominated by a xerophytic gymnosperm vegetation producing Classopollis pollen (Alvin, 1982).

\section{CONCLUSIONS}

Nonmarine palynological assemblages recovered from the halite at Site 546 and from the upper part of Lithological Unit VII (grayish red and dark gray sandy mudstones) in Hole 547B are of Rhaetian-Hettangian age. Within the limits of age resolution it is suggested that the halite at Site 546 is possibly synchronous with the upper part, at least, of Unit VII in Hole 547B, the latter being a marginal facies bordering the salt. This stratigraphic relationship is also suspected by the presence of gypsum veins in Unit VII in Hole 547B, which suggests aridity and map relations (Hinz et al., 1982; Leg 79 Scientific Party, 1982).

Based upon the ages assigned to the halite at Site 546 and Unit VII in Hole 547B, a biostratigraphic correlation with the Argo Formation (halite with shale and anhydrite interbeds) of the Scotian Shelf, offshore southeastern Canada, and the Argo Formation and lower part of the Iroquois Formation (limestone and dolomite with shale and anhydrite interbeds) of the Georges Bank Basin, offshore Massachusetts, northeastern United States, is tentatively suggested (Poag, 1982).

The onset of marine conditions probably occurred within the Hettangian associated with the fairly rapid establishment of anoxic bottom conditions. The prevalence of breccias, formed by debris flows off adjacent shelf areas, suggests tectonic instability probably associated with rifting.

Lithological Subunit VIB in Hole 547B correlates biostratigraphically with the lower part of the Iroquois Formation (anhydritic dolomite with shale and limestone interbeds) of the Scotian Shelf and part of the Iroquois Formation of the Georges Bank Basin (Poag, 1982).

The overall palynofloral content of the sample analyzed from Site 545, associated with lithological considerations and comparison with palynofloras from Site 
546 and Hole 547B, suggests that Site 545 failed to penetrate strata equivalent in age to the halite at Site 546 or Unit VII and Subunit VIB in Hole 547B.

\section{ACKNOWLEDGMENTS}

The author would like to thank Drs. R. J. Davey and G. L. Williams for their constructive criticism of the manuscript and the directors of Robertson Research International Limited for permission to publish this paper.

\section{REFERENCES}

Alvin, K. L., 1982. Cheirolepidiaceae: biology, structure and palaeoecology. Rev. Palaeobot. Palynol., 37(1/2):71-98.

Boutet, C., 1981. Etude palynoplanctologique du Trias et du Jurassique inferieur et moyen de Gresigne-Sud Quercy [Unpublished Ph.D. thesis]. Univ. Paul Sabatier, Toulouse.

Bujak, J. P., and Williams, G. L., 1977. Jurassic palynostratigraphy of offshore eastern Canada. In Swain, E. W. (Ed.), Stratigraphic Micropalaeontology of Atlantic Basin and Borderlands: Amsterdam (Elsevier), pp. 321-339.

Cornet, B., and Traverse, A., 1975. Palynological contributions to the chronology and stratigraphy of the Hartford Basin in Connecticut and Massachusetts. Geosci. Man, XI:1-33.

Hinz, K., et al., 1982. Preliminary Results from DSDP Leg 79, seaward of the Mazagan Plateau off Central Morocco. In von Rad, U., Hinz, K., Sarnthein, M. and Seibold, E. (Eds.), Geology of the Northwest African Continental Margin: Berlin, Heidelberg (Springer-Verlag), pp. 23-33.

Leg 79 Scientific Party, 1982. Off Morocco Leg 79 drills salt, red beds. Geotimes (March 1982):14-15.

Morbey, S. J., 1975. The palynostratigraphy of the Rhaetian Stage, Upper Triassic in the Kendelbachgraben, Austria. Palaeontographica Abt. B., 152:1-75.

, 1978. Late Triassic and Early Jurassic subsurface palynostratigraphy in northwestern Europe. Palinologia, num. extraord., $1: 355-365$

Poag, C. W., 1982. Stratigraphic reference section for Georges Bank Basin-depositional model for New England Passive Margin. Amer. Assoc. Geol. Bull., 66/8:1021-1041.

Van Erve, A. W., 1977. Palynological investigation in the Lower Jurassic of the Vicentinian Alps (northeastern Italy). Rev. Palaeobot. Palynol., 23(1):1-117.
Visscher, H., and Brugman, W. A., 1981. Ranges of selected palynomorphs in the Alpine Triassic of Europe. Rev. Palaeobot. Palynol., $34: 115-128$.

Date of Initial Receipt: February 18, 1983

Date of Acceptance: November 10, 1983

\section{APPENDIX}

Algae, microplankton, and miospores recorded in this chapter are listed alphabetically. All references to taxa mentioned in the text and Appendix and not listed in the reference list can be found in Morbey (1975).

Acanthomorph acritarchs

Araucariacites australis Cookson, 1947

Botryococcus sp.

Carnisporites anteriscus Morbey, 1975

Cerebropollenites mesozoicus (Couper, 1958) Nilsson, 1958

Chasmatosporites spp.

Classopollis spp. Under this heading are grouped specimens in possession of a striate equatorial region and structured intexine.

Corollina meyeriana (Klaus, 1960) Venkatachala and Goczan, 1964. Under this heading are grouped specimens that lack a striate equatorial region and structured intexine.

Crassosphaera hexagonalis Wall, 1965

Cycadopites spp.

Deltoidospora spp.

Duplexisporites problematicus (Couper, 1958) Playford and Dettmann, 1965

Echinitosporites cf. iliacoides Schulz and Krutzsch, 1961, sensu Bujak and Williams, 1977

Echinitosporites sp. A Bujak and Williams, 1977

Kraeuselisporites reissingeri (Harris, 1957) Morbey, 1975

Large leiospheres

Leptolepidites sp.

Foraminiferal test linings

Parvisaccites enigmatus Couper, 1958

Perinopollenites elatoides Couper, 1958

Porcellispora longdonensis (Clarke, 1965) Scheuring, 1970

Tasmanites newtoni Wall, 1965

Tasmanites suevicus (Eisenack, 1957) Wall, 1965

Undifferentiated bisaccates 